\title{
Impact of Online Agriculture Marketing Policy - e-NAM (electronic National Agriculture Market) on Prices and Arrivals of Agricultural Commodities in Punjab, India
}

\author{
Dharavath Pool Singh ${ }^{1}$, Chidanand Patil ${ }^{1}$ and Satyveer Singh Meena ${ }^{2 *}$ \\ ${ }^{1}$ Department of Applied Agriculture, Central University of Punjab, Bathinda, \\ Punjab State-151001, India \\ ${ }^{2}$ Department of Finance, Institute of Agri Business Management, SKRAU, \\ Bikaner, Rajasthan-334006, India \\ *Corresponding author
}

\section{A B S T R A C T}

Keywords

Agriculture, Online trading, eNAM,

APMC, Prices and

Arrivals

Article Info

\section{Accepted:}

15 January 2021

Available Online:

10 February 2021
The Govt. of India has created an online trading display place named National Agricultural Market or e-NAM for marketing agricultural commodities. e-NAM accommodates farmers with smooth marketing procedures for their products at a better price than the regular Agricultural Produce Market Committee's (APMC's). Recently new 25 commodities are added to the NAM on 29-08-2020 for trading. Now a total of 175 commodities are available for trade (www.enam.gov.in). This paper make an attempt to analysis of the market profile, status of e-NAM implementation in Mansa APMC of India's Punjab state, and prices of major agricultural commodities prior to and after e-NAM implementation was done. In terms of variation in different commodities prices specially in cotton prices, which was the primary commodity traded in the APMC, before e-NAM was executed in few selected APMC, it was observed that the coefficient of variation was high (11.54\%) as compared to the after unification of APMC with e-NAM (10.94\%). Increases in cotton post-unification prices are due to more farmers' and traders' participation in the e-NAM system. Though, there is huge possibility for higher price discovery in the e-NAM system if further traders are encouraged to take part and invite aggressive bidding. It may be done by creating awareness and organized training programs for traders and farmers.

\section{Introduction}

Until independence, the government's essential worry about agricultural marketing was to hold food prices in control for customers and agro-raw materials in control for industry (Crawford, 1997).However, after independence, the need to protect farmers' interests and make available them with opportunity prices to increase agricultural commodity output was still felt (Wikipedia, 2020). Recognizing faults such as losses to 
farmers in terms of low rates, higher marketing costs, and significant physical losses of goods in the agricultural marketing system suffered by farmers, the administration has implemented a lot of compulsory regulations from time to time to develop a framework for tracking consumer behavior. In India, a rural display is administered by a set of public possessed discount markets set up during the pilgrim period under the APMC Act. The administrative instrument, which is over 100 years of age, presumably, has set up some excellent highlighting rehearses ((planning commission, 2011). Not with standing, because of different administrative instruments and limitations on exchanging farming wares, it is laden with the frameworks' weaknesses. Against this setting, India's Government carried out changes to the division through the Model Act 2003 and APLM Act 2017. The Model Act imagines expulsion of restrictions on the growth of wares, the single duty of market charge, advancement of elective advertising framework, advancement, and ICT. The goal of every one of these endeavors is to get changes, for most of the part, to expel limitations in agrarian exchange and prompt a problematic situation by guaranteeing increasingly more support of traders by utilizing ICT (Dalwai, 2017).

As mentioned about the sophisticated administrative instrument and limitations, the Union Budget 2014-15 proposed the possibility of a bound together normal market stage, propelled on 14 April 2016, a Pan- India electronic exchanging entryway known as National Agriculture Market (e-NAM). It is a virtual market connecting the current APMC Mandis electronically with a subject of "one country, one market." e-NAM advances consistency, smoothing out of systems over the incorporated markets, evacuates the data hole among purchasers and dealers, and advances ongoing value disclosure dependent on genuine interest and flexibly in the market.
It gives straightforwardness in the closeout procedure and access to an across the nation market to both the gatherings. The present study was undertaken to analyze the market profile, status of e-NAM implementation in Mansa APMC of India's Punjab state, and prices of major agricultural commodities earlier than and subsequent to e-NAM implementation in Mansa APMC (e-NAM2018).

\section{Materials and Methods}

\section{Selection of market}

Select the market, e-NAM transactions of the significant market were recorded and based on the highest e-NAM transactions, APMC Mansa was selected. The significant commodities were cotton, paddy, and wheat.

This research conducted in the New Grain Market Mandi, APMC Mansa. The time frame of this study was from November 2019 to June 2020 in APMC Mansa. The e-NAM was introduced in APMC Mansa from 18-March2018; at the time of the second execution of eNAM in India, APMC Mansa was interlinked specially with the e-NAM web portal. The study was based on primary as well as secondary data. Primary and secondary data was collected from mandi officials and APMC officials, Agmarknet, and e-NAM Portal. The present study was exploratory research. The methods used for data analysis included tabulation in the view of the cited objectives.

They were interpreted by absolute, relative change, average (mean), standard deviation, and variation coefficient.

\section{Results and Discussion}

The outcomes and conversation of the examination are introduced below. Based on the objectives in view, the results are shown under the following heads; 
To analyze the market profile and the status of e-NAM in Mansa APMC

To analyze the arrival and prices of significant commodities before and after e-NAM implementation in Mansa APMC

\section{Market profile and the status of e-NAM in APMC Mansa}

Mansa Mandi was established in the year 1956 as a rural market in Mansa district under the control of the district agriculture marketing committee. It is known as the old grain market in Mansa city (Punjab Govt GAZ, 1953). In 1960-61, the market was regulated under APMC. Government of Punjab gazette 8November-1963, Mandi is notified as a regulated market under Punjab Agricultural Produce Market Act1 961 (Department of Agricultural and Farmers Welfare, 2019). Under this Mandi, it has two sub-market yards.

At Sardulgarh-starting from the old bridge of river Ghagar towards the new Ghagar Bridge and the west wing of the village, Sardulgarh.

At Bhikhi-starting from the crossing of Mansa-Budhalada road towards the police station Bhikhi and the north side of village Bhikhi and then from the police station to Government High School. Punjab Government has implemented e-NAM in 19 APMCs of the State (enam.gov.in). The Mansa Mandi profile in terms of year of establishment, class of Mandi, notified area, notified commodities being traded, the strength of different functionaries, and warehouse facilities inside the Mandi are presented in Table 1.

\section{Implementation of e-NAM in APMC Mansa}

To requisite infrastructure for the development of e-NAM Mandis in the State, the Central
Government provides financial assistance of 75 lakhs per Mandi (sfacindia). Out of total assistance, up to Rs. 30 lakhs per market is for IT and quality assaying lab-related infrastructure development, up to Rs.40 lakhs is for the development of sorting/grading and packaging facility, and the remaining Rs.5 lakhs are for compost unit development

The profile of e-NAM in APMC Mansa in terms of establishment, phase of implementation and present infrastructure available in APMC Mansa are shown in Table 2.

The necessary facilities in the Mansa APMC, such as electronic bidding, display board, POS machine, weight machine, assaying labs, are necessary for the successful implementation of e-NAM.

The APMC Mansa found that it does not have any necessary facilities integrated with the eNAM portal. However, there were missing links among the APMC Mansa concerning the integration of weighment and warehouses with the e-NAM portal. These missing links are limiting the online trade in the Mandi.

Table 3 shows the implemented e-NAM infrastructure's status in the electronic gate pass, bidding and display board.

\section{Comparison between recommended and existing e-NAM structure}

Small Farmers Agri-business Consortium has prescribed requisite human resources and infrastructure for the execution of e-NAM.

Hence, to ascertain whether the APMC Mansa has the infrastructure or not, a comparison was made, and the results of the same are presented in Table 4. It was revealed from the results presented in the table that most of the markets did not have requisite infrastructure 
except for computers and printers. However, the market had the requisite internet speed required for online trading.

Further, a sufficient number of moisture meters and weighing scales were available in the mandi, and they are not using the trading the commodity, respectively. The mandi had quality testing equipment and sampling equipment.

Hence, it suggested that gradually the market should have the requisite infrastructure as recommended by SFAC, but it was not functioning properly under e-NAM of APMC Mansa.

\section{Stakeholders registered}

E-NAM is a platform that is expected to provide a win-win solution to all the stakeholders are connected with the graceful chain of agricultural produce.

In Punjab, every Market Committee has proactively registered farmers with the necessary details like name, village, mobile number, bank details, producer company details.(Primary observation in APMC Mansa).

All the commission agents and traders of the e-NAM Mandi of APMC Mansa have been linked to e-NAM. Punjab state did not convert the license of commission agents/traders into a unified license. If the license is unified, traders/commission agents can perform intermandi trade with a single license.

The bank-related information has been kept optional. Some of the farmers and Farmer Producer Organizations have shown reluctance to share their bank details and participate (Primary discursion with the APMC Mansa officer). The details of stakeholder registration are given in table 5 and table 6. It was revealed from the table that a maximum number of farmers were registered in the state Punjab and APMC Mansa under the e-NAM. A similar trend was recorded for other market functions.

\section{Percentage of commodity traded within Mandi under e-NAM Platform in New Grain Market Mansa APMC}

The respective percentage share calculated based on the arrival of commodities (provided by these ller during Gate-Entry) and traded commodity (up to the

creation of sale agreement). It also depicts that APMC Mansa in this mandi trading is not performing under e-NAM. Data was collected from a farmer after the produce sale to retailers and the Cotton Corporation of India. Data was updated to the e-NAM portal as 100 percent of the notified commodity's online trading within the mandi through e-NAM.

\section{Bidding performance}

A scientific method of price discovery, transparency, and competition is one of the objectives of e-NAM. It may not be achieved all the way through the manual method of bidding operation. The mandi's trade efficiency is assessed based on the lots managed by the markets even during peak season.

As per the SFAC recommendation, bidding is necessary for the purchase of any product, but the new grain market, Mansa, has not started any bidding activities.

They are just updating the data without assessing the lot bidding under the e-NAM. In this market, Arhtiyas, commission agents, and intermediaries play a significant role in selling the farm produce. 
Table.1 Implementation of e-NAM APMC Mansa

\begin{tabular}{|c|c|c|}
\hline \multirow{2}{*}{ S. No. } & Particulars & $\begin{array}{c}\text { Marketing committee Mansa } \\
\text { (Punjab state Marketing Board) }\end{array}$ \\
\cline { 3 - 3 } & & New Grain market \\
\hline $\mathbf{1}$ & District & Mansa \\
\hline $\mathbf{2}$ & Year of Establishment & 1956 \\
\hline $\mathbf{3}$ & Notified Area(No. of Gram Panchayat) & 73 \\
\hline $\mathbf{4}$ & Notified Commodities & Rice, Cotton \\
\hline $\mathbf{5}$ & Godowns(Number) & NA \\
\hline $\mathbf{6}$ & Godowns (Capacity)in MT & 69 \\
\hline $\mathbf{7}$ & No. of Traders & 521 \\
\hline $\mathbf{8}$ & No. of Commission Agents & 17 \\
\hline $\mathbf{9}$ & Officers/Staff & 5 \\
\hline $\mathbf{1 0}$ & Staff(Outsourced) & \\
\hline
\end{tabular}

Source: Data Collected from APMC Mansa Note: NA - Not Available

Table.2 Status of manpower and infrastructure availability e-NAM in APMC Mansa

\begin{tabular}{|c|c|c|c|}
\hline \multirow{2}{*}{ S. No. } & Particulars & Units & $\begin{array}{c}\text { Marketing committee Mansa } \\
\text { (Punjab state Marketing Board) }\end{array}$ \\
\cline { 4 - 4 } & & & New grain market \\
\hline $\mathbf{1}$ & e-NAM Introduced & Date & 18-March-2018 \\
\hline $\mathbf{2}$ & NAM Bidding Hall & Number & NA \\
\hline $\mathbf{3}$ & e-Gate entry Facility & Number & NA \\
\hline $\mathbf{4}$ & e-Gate entry at Display Shed & Number & NA \\
\hline $\mathbf{5}$ & Net Connection-e NAM Hall & Mbps & NA \\
\hline $\mathbf{6}$ & Net Connection Gate Entry & Mbps & 1 \\
\hline $\mathbf{7}$ & Generator & Number & NA \\
\hline $\mathbf{8}$ & Electronic Weighing & Number & NA \\
\hline $\mathbf{9}$ & POS Machine & Number & 3 \\
\hline $\mathbf{1 0}$ & Data Entry Operator & Number & 1 \\
\hline $\mathbf{1 1}$ & IT Staff & Numbers & 1 \\
\hline $\mathbf{1 2}$ & Mandi Analyst & Numbers & NA \\
\hline $\mathbf{1 3}$ & Grading Staff & Numbers & \\
\hline
\end{tabular}

Source: Respective of Mandi officer and primary observation Note: NA - Not Available 
Table.3 Status of implemented e NAM infrastructure in sample Mandi

\begin{tabular}{|c|c|c|}
\hline \multirow{2}{*}{ S. No. } & Particulars & $\begin{array}{c}\text { Marketing committee Mansa } \\
\text { Punjab state Marketing Board) }\end{array}$ \\
\cline { 3 - 3 } & & New grain market \\
\hline $\mathbf{1}$ & Electronic Gate Passes & Yes \\
\hline $\mathbf{2}$ & Electronic Bidding & No \\
\hline $\mathbf{3}$ & Electronic Display & No \\
\hline $\mathbf{4}$ & Exit Pass Generated & No \\
\hline $\mathbf{5}$ & e-Agreement & Yes \\
\hline $\mathbf{6}$ & Generation of Sale Receipt & Yes \\
\hline $\mathbf{7}$ & Assaying Lab & Yes \\
\hline $\mathbf{8}$ & Announcing highest bid price to the farmer by & No \\
\hline $\mathbf{9}$ & SMS & No \\
\hline $\mathbf{1 0}$ & Integration of weighment with e-NAM portal & No \\
\hline $\mathbf{1 1}$ & Online Settlement & No \\
\hline
\end{tabular}

Source:Primaryobservationbyresearchinvestigator\&informationcollectedfromthe respective farmer, trader, and mandi officers.

Table.4 SFAC recommended existing manpower and infrastructure in sample mandi

\begin{tabular}{|c|c|c|c|}
\hline Particulars & Description & Required Unit/ No. & $\begin{array}{l}\text { Available Unit/No in } \\
\text { APMC Mansa }\end{array}$ \\
\hline \multirow{5}{*}{ Gate entry } & Computer & 2 & 0 \\
\hline & Printer & 2 & 0 \\
\hline & Handhold device & 2 & 0 \\
\hline & Computer Operator & 2 & 0 \\
\hline & Internet & 5-6 MBPS & 0 \\
\hline \multirow{5}{*}{$\begin{array}{l}\text { Quality } \\
\text { testing }\end{array}$} & Building for lab & 1 & 1 \\
\hline & Lab Equipment & & \\
\hline & Moisture Meter & 2 & 0 \\
\hline & Weighing Scale & 2 & 0 \\
\hline & Computer & 1 & 1 \\
\hline \multirow{6}{*}{ lab } & d) Printer & 1 & 1 \\
\hline & Other ancillary equipment required for quality testing & As for needed & 0 \\
\hline & Sampling Equipment & As for needed & 0 \\
\hline & Sampler & 2 & 0 \\
\hline & Lab Analyst & 2 & 0 \\
\hline & Internet & 5-6 MBPS & 5-6 MBPS \\
\hline \multirow{6}{*}{ E-auction } & e-Auction Hall & 1 & 1 \\
\hline & Projector/LCD Screen & 1 & 1 \\
\hline & Computer for administration & 1 & 1 \\
\hline & Computer for users & 5 & 4 \\
\hline & Internet & 5-6 MBPS & 5-6 MBPS \\
\hline & Human resources/Computer Operator & 5 & 3 \\
\hline \multirow[t]{2}{*}{ Weight bridge } & Electronic Weighbridge & 1 & 5 \\
\hline & Weigh Scale & - & 0 \\
\hline \multirow{4}{*}{ Exist gate } & Computer & 2 & 0 \\
\hline & Printer & 2 & 0 \\
\hline & Computer Operator & 2 & 0 \\
\hline & Internet & 5-6 MBPS & 0 \\
\hline \multirow[t]{2}{*}{ Power backup } & Generator & 1 & 1 \\
\hline & UPS & As for needed & 0 \\
\hline
\end{tabular}


Table.5 Overall Stakeholders' registration in e-NAM Mandi in Punjab, till 1 May 2020

\begin{tabular}{|c|c|c|c|c|c|}
\hline \multirow{2}{*}{ S. No. } & Punjab & \multicolumn{4}{|c|}{ Stake Holder's } \\
\cline { 3 - 5 } & & Farmer's & FPOs & Trader's & Commission Agent \\
\hline $\mathbf{1}$ & Stake holder in e-NAM & $2,10,438$ & 1 & 1,385 & 5,256 \\
\hline
\end{tabular}

Source: enam.gov.in

Table.6 Stakeholders' registration in e-NAM APMC Mandi Mansa, till 1 May 2020

\begin{tabular}{|c|c|c|c|c|c|}
\hline \multirow{2}{*}{ S. No. } & Punjab Mandi Board (PMB) & \multicolumn{4}{|c|}{ Stake Holder's } \\
\cline { 3 - 6 } & & Farmer's & FPOs & Trader's & Commission Agent \\
\hline $\mathbf{1}$ & New Grain Market Mansa & 34,838 & 0 & 69 & 521 \\
\hline
\end{tabular}

Source: Primary data from APMC Mansa

Table.7 Arrivals and price of cotton Before E-NAM

\begin{tabular}{|c|c|c|c|c|c|c|}
\hline $\begin{array}{c}\text { S. } \\
\text { No. }\end{array}$ & Year & Month & $\begin{array}{c}\text { Arrivals } \\
\text { (Tonnes) }\end{array}$ & $\begin{array}{c}\text { Minimum } \\
\text { Price(Rs/Quintal) }\end{array}$ & $\begin{array}{c}\text { Maximum } \\
\text { Price(Rs/Quintal) }\end{array}$ & $\begin{array}{c}\text { Modal } \\
\text { Price(Rs/Quin } \\
\text { tal) }\end{array}$ \\
\hline $\mathbf{1}$ & 2017 & February & 1840.00 & 6225 & 4900 & 5300 \\
\hline $\mathbf{2}$ & 2017 & March & 1221.00 & 6340 & 5100 & 5500 \\
\hline $\mathbf{3}$ & 2017 & April & 10.00 & 6115 & 5250 & 5500 \\
\hline $\mathbf{4}$ & 2017 & May & 210 & 6100 & 5100 & 5500 \\
\hline $\mathbf{5}$ & 2017 & June & $75^{*}$ & 6000 & 5200 & 5600 \\
\hline $\mathbf{6}$ & 2017 & August & $46^{*}$ & 4721 & 3925 & 4300 \\
\hline $\mathbf{7}$ & 2017 & September & 390 & 4750 & 3700 & 4300 \\
\hline $\mathbf{8}$ & 2017 & October & 60202 & 4850 & 3935 & 4100 \\
\hline $\mathbf{9}$ & 2017 & November & 156 & 4865 & 3800 & 4500 \\
\hline $\mathbf{1 0}$ & 2017 & December & 695 & 5420 & 4100 & 4600 \\
\hline $\mathbf{1 1}$ & 2018 & January & 1003.7 & 5415 & 4200 & 4500 \\
\hline $\mathbf{1 2}$ & 2018 & March** & 1482 & 5020 & 3800 & 4900 \\
\hline
\end{tabular}

Source: *Data from APMC Mansa official and agmarknet.gov.in,

Note: **Up to 18-March-2018

Table.8 Arrivals and price of cotton after E-NAM

\begin{tabular}{|c|c|c|c|c|c|c|}
\hline S. No. & Year & Month & $\begin{array}{c}\text { Arrivals(T } \\
\text { ones) }\end{array}$ & $\begin{array}{c}\text { Minimum } \\
\text { Price(Rs/Quintal) }\end{array}$ & $\begin{array}{c}\text { Maximum } \\
\text { Price(Rs/Quintal) }\end{array}$ & $\begin{array}{c}\text { Modal } \\
\text { Price(Rs/Quintal) }\end{array}$ \\
\hline $\mathbf{1}$ & 2018 & July & 7.7 & 5470 & 5470 & 5470 \\
\hline $\mathbf{2}$ & 2018 & September & 1702.2 & 5220 & 5630 & 5430 \\
\hline $\mathbf{3}$ & 2018 & October & 8350 & 5115 & 5355 & 5250 \\
\hline $\mathbf{4}$ & 2018 & November & 5030 & 5360 & 5575 & 5450 \\
\hline $\mathbf{5}$ & 2018 & December & 6714.1 & 5300 & 5475 & 5400 \\
\hline $\mathbf{6}$ & 2019 & January & 8230 & 5355 & 5490 & 5400 \\
\hline $\mathbf{7}$ & 2019 & March & 4270 & 5995 & 6125 & 6040 \\
\hline $\mathbf{8}$ & 2019 & April & 3055.1 & 6295 & 6320 & 6300 \\
\hline $\mathbf{9}$ & 2019 & September & 520.3 & 5661 & 5721 & 5500 \\
\hline $\mathbf{1 0}$ & 2019 & October & 6630.8 & 5000 & 5230 & 5100 \\
\hline $\mathbf{1 1}$ & 2019 & November & 10338.8 & 5135 & 5275 & 5160 \\
\hline $\mathbf{1 2}$ & 2019 & December & 9324.5 & 5000 & 5450 & 5300 \\
\hline
\end{tabular}

Source: agmarknet.gov.in, *Data, from 19 March 2018 onwards 
Analyses of arrival and prices of significant commodities before and after E-NAM in Mansa APMC

Appearance and costs of significant products previously, then after the fact the Unification of selected APMC with the e-NAM platform have been analyzed from the collected data. Month wise arrival and prices for the year from 2017-18 to 2018-19 were analyzed.

\section{Mansa APMC}

In APMC Mansa, the article of trade that was brought by the farmers to the market was cotton.

Arrivals and prices of cotton have been analyzed, and it was identified that the total arrival of cotton in APMC Mansa increased over the year, which can be seen from table 7 . When APMC was unified with the e-NAM platform in March 2018, there was a slight decrease in the arrivals compared to 2017-18.

\section{Before e-NAM}

Average arrivals (tonnes) 5610.892 Average Modal price (Rs. /Qtl) 4883.333

Standard Deviation (tonnes) 17202.76 Standard deviation (Rs. /Qtl) 563.8074

Coefficient of variance (\%) 306.595 Coefficient of variance (\%) 11.54554

\section{After unification with e-NAM}

Average arrivals (tonnes) 5347.792 Average Modal price (Rs. /Qtl) 5483.333

Standard Deviation (tonnes) 3479.659294 Standard deviation (Rs. /Qtl) 348.3293

Coefficient of variance (\%) 65.0672186 Coefficient of variance (\%) 6.352511

\section{Changes after unification with e-NAM}

Absolute change (tonnes) -263.1 Absolute change (Rs./Qtl) 600

Relatively change (\%) 4.689 Relatively change (\%) 10.94225. The arrival of cotton in Mansa APMC (Table 8) have analyzed and found an absolute change of -263.1 tonnes and a comparative change of 4.689 percent after the Unification of this APMC with the e-NAM system. It may be due to the detail that more sellers and traders participate post-unification of APMC than pre-unification. However, regarding the variation in the arrivals, it was identified that the coefficient of variation was more in the case of pre-unification with 306.595 percent of CV compared to postunification of e-NAM with 65.06 percent.

The highest percentage of CV pre-unification was a considerable variation in the monthly arrival of cotton to the APMC.

Regarding the monthly modal prices of cotton in Mansa APMC was presented in table 7 and table 8 . It can be seen from the table that there was an increase in the average modal price of cotton by Rs. 600 per quintal after implementation of e-NAM with this APMC and showing a comparative change of 10.94 percent over the pre-unification prices.

In terms of deviation in prices, before e-NAM was implemented in the selected APMC, it was observed that the coefficient of variation was more $(11.54 \%)$ compared to the Unification of APMC with e-NAM (10.94\%). An increase in the prices of cotton postunification may be due to more farmers' and traders' participation in the e-NAM system. Helping e-NAM sellers realized high prices. However, there is still scope for higher price discovery in the e-NAM system if more traders are encouraged to participate and invite aggressive bidding. It may be done by creating 
awareness and organized training Programmes for the traders, the functions and benefits of the e-NAM system.

In the Mansa APMC, the commodity that was brought by the farmers and traders for trading in the e-NAM system was cotton. So prices and arrivals of cotton were analyzed before and after the unification of e-NAM with the APMC. It was found that the significant commodity brought to the APMC by the sellers for sale in the e-NAM auction was a single commodity, i.e., cotton. The number of traders and farmers registered with the APMC was less during APMC Mansa's postunification with e-NAM. The staffing pattern and the staff's strength in the selected APMC were very few compared to the government guideline given for the APMCs. It was observed that APMC Mansa had fixed the market charges. In the selected APMC, 1 percent of the market fee has been fixed for cotton. After the monthly arrival of cotton pre and post-unification of e-NAM in the APMC has been analyzed, it was found that there existed an absolute negative change and relative change of -263.1 tonnes and 4.689 percent, respectively. It has also been seen that there was a change in the modal price of cotton after the unification of the selected APMC with the e-NAM system. The absolute change and relative change were found to be Rs-600 per quintal and 10.94 percent, respectively.

Regarding the variation in terms of arrival, it was found that the coefficient of variation was more in of pre-unification in the selected APMC with 306.59 percent CV compared to post-unification of e-NAM with 65.06 percent $\mathrm{CV}$ respectively. Whereas in case of prices, it was 11.54 percent CV pre-unification and 6.35 percent CV post-unification APMC. However, the highest percentage of $\mathrm{CV}$ pre-unification was a considerable variation in the monthly arrival of cotton to the APMC. Since, largely respondents were ranging from the average age group of 45 years, indicated that sample distribution was mostly taken the middle age lot, resulting from observing an enthusiastic and enlarged response to the research study's various objectives, as were responded by the sample respondents during the scheduling. As the middle age, farmers were slanted to analyze and learn different parts of the electronic method of National Agriculture Marketing perspectives.

\section{References}

Acharya. (2017). A study on the implementation of prices and marketing policies in e-trading. Agricultural Economics Research Review.Vol.30:1-12

Arayesh. (2015). Conducted a study to investigate financial and legal- security infrastructure influencing the electronic marketing of agrarian items from the perspective of jalid agricultural organization specialists of the Ilam area through a graphic review.

Bachaspati. (2018). An economic study of the electronic trading portal for the National Agriculture Market (e-NAM) on selected Agricultural Produce Market Committees (APMCs) of Chhattisgarh. Raipur: Indira Gandhi Viswavidyalaya.

Chanti. (2017). Agriculture policy in India a study of the living conditions of rural villagers due to the green revolution. International Journal of Scientific Research and Management (IJSRM), 6863-6868.

Crawford, I. M. (1997). Agricultural and Food Marketing Management Published by Food and Agriculture Organization of The United Nations Rome M-62 ISBN 92-5-103904-6 retrieved from www.fao.org/3/w3240e/W3240E00.ht m\#TOC 
Dalwai, A. (2017). Model act, Agricultural produce and Livestock marketing (Promotion and Facilitation Act, 2017) issued by Ministry of Agriculture \& Farmers' Welfare, Department of Agriculture, Cooperation \& FW Government of India. Retrieved from agricoop.nic.in/sites/default/files/APL M_ACT_2017_1.pdf

Department of Agricultural and Farmers Welfare (2019). Government of Punjab, Retrieved from https://agri.punjab.gov.in/?q=welcome -district-mansa-punjab-introduction

e-NAM (2018). Small farmers Agribusiness Consortium, Ministry of Agriculture \& Farmers' Welfare, Department of Agriculture, Cooperation \& FW Government of India. Retrieved from https://enam.gov.in/web/successstories/process-related-improvement

Maru (2018). Agriculture, Farming, Food, Nutrition, and Technology: From the "green revolution" to the "Ever Green Revolution": India's Case. Global Forum on Agricultural Research, Page No. 1-8.

Maru, Ajit. (2013). Agriculture, Farming, Food, Nutrition, and Technology:
From the "green revolution" to the "Ever Green Revolution": India's Case. India: GFAR.

Planning Commission, Government of India (2011) Report of the Working Group on Agricultural Marketing Infrastructure, Secondary Agriculture And Policy Required for Internal and External Trade, retrieved from Microsoft Word - Working Group Report on Marketing -Draft.doc (niti.gov.in)

Tyngkan. (2018). Impact of ElectronicNational Agriculture Market (e-NAM) on the Income of Farmers in Raipur and Dhamtari I Agricultural Produce Market Committees (APMCs) of Chhattisgarh. Chhattisgarh: Indira Gandhi KRISHI Vishwavidyalaya Raipur.

Wikipedia, (2020). Agricultural produce market committee. In Wikipedia, The Free Encyclopedia. Retrieved 11:01, January 8, 2021, from https://en.wikipedia.org/w/index. php?title=Agricultural_produce_marke t_committee\&oldid=998629723

\section{How to cite this article:}

Dharavath Pool Singh, Chidanand Patil and Satyveer Singh Meena. 2021. Impact of Online Agriculture Marketing Policy - e-NAM (electronic National Agriculture Market) on Prices and Arrivals of Agricultural Commodities in Punjab, India. Int.J.Curr.Microbiol.App.Sci. 10(02): 1573-1582. doi: https://doi.org/10.20546/ijcmas.2021.1002.187 